OPEN ACCESS

Edited by:

Roberto Narcisi,

Erasmus University Rotterdam,

Netherlands

Reviewed by:

Roberta Tasso,

Ospedale San Martino (IRCCS), Italy Anna Lange-Consiglio,

University of Milan, Italy

${ }^{*}$ Correspondence:

Aleksandra Leszczynska

aleksandra.leszczynska@gmail.com

Specialty section:

This article was submitted to Tissue Engineering and Regenerative

Medicine,

a section of the journal Frontiers in Bioengineering and Biotechnology

Received: 31 October 2017 Accepted: 22 January 2018 Published: 09 February 2018

Citation:

Leszczynska A and Murphy JM (2018) Vascular Calcification: Is it rather a Stem/Progenitor Cells Driven Phenomenon?

Front. Bioeng. Biotechnol. 6:10. doi: 10.3389/fbioe.2018.00010

\section{Vascular Calcification: Is it rather a Stem/Progenitor Cells Driven Phenomenon?}

\author{
Aleksandra Leszczynska ${ }^{1 *}$ and J. Mary Murphy ${ }^{2}$ \\ ${ }^{1}$ Regenerative Medicine Institute, Cedars-Sinai Medical Center, Los Angeles, CA, United States, ${ }^{2}$ Regenerative Medicine \\ Institute, National University of Ireland Galway, Galway, Ireland
}

Vascular calcification (VC) has witnessed a surge of interest. Vasculature is virtually an omnipresent organ and has a notably high capacity for repair throughout embryonic and adult life. Of the vascular diseases, atherosclerosis is a leading cause of morbidity and mortality on account of ectopic cartilage and bone formation. Despite the identification of a number of risk factors, all the current theories explaining pathogenesis of $\mathrm{VC}$ in atherosclerosis are far from complete. The most widely accepted response to injury theory and smooth muscle transdifferentiation to explain the VC observed in atherosclerosis is being challenged. Recent focus on circulating and resident progenitor cells in the vasculature and their role in atherogenesis and VC has been the driving force behind this review. This review discusses intrinsic cellular players contributing to fate determination of cells and tissues to form ectopic cartilage and bone formation.

Keywords: vascular calcification, stem cells, atherosclerosis, pericytes, progenitor cells

\section{INTRODUCTION}

Vascular calcification (VC) is an important complication of atherosclerosis contributing to cardiovascular morbidity and mortality (Alexopoulos and Raggi, 2009), given the increased risk of heart attack with calcified coronaries and the growing incidence of calcified aortic stenosis (Rajamannan et al., 2007). It is increasingly being accepted that VC is far from a passive degenerative process as thought for the last few decades. Rather, the most recent concept is that VC is an active, organized, complex, and highly regulated process reflecting the plasticity of vasculature (Bostrom, 2016). In particular, calcification of atherosclerotic plaque recapitulates virtually the same biologic reactions inherent to normal physiologic bone formation (Neven and D'Haese, 2011). This recapitulation is evidenced by the presence of bone-like structures in the atherosclerotic arteries and valves, which in many cases is structurally complete trabecular bone (Hunt et al., 2002). This resemblance is not just at the macroscopic level but even at microscopic level shows features such as completely formed marrow cavities with hematopoietic and marrow stromal cells (Bunting, 1906; Soor et al., 2008). Energy dispersive X-ray analysis has shown that the mineral in vascular lesions is hydroxyapatite (Ewence et al., 2008) the same mineral as in bone, not just amorphous calcium phosphate.

Inflammation has been shown to be a contributing factor (Bessueille and Magne, 2015). The expression of growth factors, matrix proteins, and other bone-related proteins that are involved in both the initiation and inhibition of mineralization supports the dogma of $\mathrm{VC}$ being a cell controlled event (Dallas and Bonewald, 2010). Calcifying vascular cells (CVCs), a subpopulation of vascular smooth muscle cells (VSMCs), that form bone-like calcifying nodules, have been found (Watson et al., 1994; Ting et al., 2011). In fact, the likelihood for the presence of a number of stem progenitor niches 
and/or lineages in vasculature has been described (MartinezAgosto et al., 2007; Bautch, 2011). Therefore, despite the fact that the understanding of these resident stem progenitor populations is currently at an early stage, tantalizing prospects for their biological and pathological role are being envisaged. This review focuses on different resident and circulating cells that play a role in ectopic cartilage and bone formation in the vessel wall.

\section{PROGENITOR STEM CELLS IN VC}

A number of cell types have been implicated in VC (Table 1). The cells in all three layers of the vessel wall (Media, Intima, and Adventitia) respond to cues in local microenvironment and undergo chondrogenic/osteogenic differentiation. Along with these resident cells, circulating cells have been shown to migrate into the vessel wall and contribute to $\mathrm{VC}$.

\section{Smooth Muscle Progenitor Cells (SMPCs) and Smooth Muscle Cells (SMCs)}

Smooth muscle cell proliferation and matrix protein synthesis, including collagen, elastin, and/or proteoglycans, lead to plaque accretion (Bentzon et al., 2006, 2007) making fibrous tissue a major component of plaque (Cappendijk et al., 2005) and may contribute significantly to coronary artery stenosis (Kataoka et al., 2009). The risk of plaque rupture and a subsequent thrombotic event increases substantially with scarcity of SMCs in the fibrous cap (Schwartz et al., 2000). They also play a role in healing the ruptured plaque by secretion of ECM (Mann and Davies, 1999; Bentzon et al., 2007). However, this healing may result in increased plaque size causing further stenosis (Mann and Davies, 1999; Burke et al., 2001). SMCs found in plaque may be sourced from locally available preexisting SMCs which migrate to the outer layer of plaque (Hu et al., 2004). The SMCs, present in media and intima of the vessel wall, but more importantly cells from the media (Zoll et al., 2008), may form the fibrous component of the plaque while acquiring a synthetic and migrating phenotype through a process called phenotypic modulation (Hao et al., 2006).

TABLE 1 | Potential cell types in vascular calcification.

\begin{tabular}{|c|c|c|}
\hline Cell types & Source/location & Ref. \\
\hline SMCs & Resident & $\begin{array}{l}\text { Speer et al. (2009), Tintut et al. (1998), } \\
\text { and Speer et al. (2009) }\end{array}$ \\
\hline SMC progenitors & Resident & $\begin{array}{l}\text { Kramann et al. (2016) and Bardeesi } \\
\text { et al. (2017) }\end{array}$ \\
\hline $\begin{array}{l}\text { Endothelial } \\
\text { progenitors }\end{array}$ & Resident & $\begin{array}{l}\text { Wirrig and Yutzey (2014) and Yao et al. } \\
\text { (2015) }\end{array}$ \\
\hline $\begin{array}{l}\text { Circulating stem } \\
\text { cells progenitors }\end{array}$ & Circulating & Cho et al. (2013) and Hu et al. (2003) \\
\hline HSCs & Circulating & $\begin{array}{l}\text { Cianciolo et al. (2016), Nakahara et al. } \\
\text { (2017), and Sata et al. (2002) }\end{array}$ \\
\hline MSCs & Circulating & Liao et al. (2012) \\
\hline Pericytes & Resident & $\begin{array}{l}\text { Canfield et al. (2000), Davaine et al. } \\
\text { (2014), Bardeesi et al. (2017), and } \\
\text { Kirton et al. (2006) }\end{array}$ \\
\hline Adventitial cells & Resident & $\begin{array}{l}\text { Tigges et al. (2013), Kramann et al. } \\
\text { (2016), and Bussolati et al. (2017) }\end{array}$ \\
\hline
\end{tabular}

This hypothesis that SMC recruitment and phenotypic modulation is being challenged with suggestions that differentiation of progenitor cells such as hematopoietic stem cells (HSCs) contributes to pathogenesis of atherosclerosis (Sata et al., 2002). Also, another possibility suggests that migration of progenitor cells from adventitia contributes to atherosclerotic plaque. Bone marrow-derived circulating progenitor cells have also been claimed as the source of a sizeable proportion of SMCs found in the atherosclerotic lesion (Tanaka et al., 2008). According to some researchers, the phenotypical differences between contractile SMCs with an abundance of myofilaments and synthetic SMCs with plenty of rough ER and golgi complexes do not suggest phenotypic modulation but rather hint toward different sources, such as a subpopulation in the arterial media with a synthetic phenotype (Frid et al., 1994), stem cells in adventitia (Hu et al., 2004; Torsney et al., 2007) or circulating SMPCs (Saiura et al., 2001). In the case of plaque rupture, local SMCs have been reported to have short telomeres and other markers of senescence (Matthews et al., 2006; Minamino and Komuro, 2008), thus suggesting that rupture healing SMCs are not locally proliferating SMCs and may very well be derived from circulating progenitor cells. This is also suggested by the fact that circulating cells can be induced to express SMC proteins like $\alpha$-smooth muscle actin ( $\alpha$-SMA) or smooth muscle myosin heavy chain. Furthermore, studies have showed that mesenchymal stem cells (MSCs) express $\alpha$-SMA protein and so also do stem cells derived from the arterial wall (da Silva Meirelles et al., 2006; Klein et al., 2011). The role of SMPCs in atherosclerosis is more complicated. The severity of luminal stenosis has been related to SMPCs, whereas a decrease in SMPC number may be involved in causing a thinner neointima and unstable plaque.

Thus, over the years, research investigating the origin of SMCs in atherosclerotic lesions has swung from an underlying medial origin to circulating progenitor cells of bone marrow origin. However, there are reports with detailed studies showing that the contribution of circulating bone marrow-derived cells to intimal tissue is less likely (Hu et al., 2002; Hillebrands et al., 2003; Daniel et al., 2010). In one study, the authors investigated the origin of SMCs at the healed plaque rupture sites and showed that SMCs healing the plaque ruptures originate from the local vascular wall (Bentzon et al., 2007).

\section{Endothelial Progenitor Stem Cells and Circulating Progenitor Stem Cells}

The functional integrity of the endothelial layer to prevent atherogenic processes is crucial. The known risk factors of coronary artery disease have been shown to induce apoptosis in endothelial cells (ECs), leading to disruption of monolayer integrity (Rossig et al., 2001; Urbich and Dimmeler, 2004b). In atherosclerosis, activation of the damaged ECs triggers the development of the lesions (Zampetaki et al., 2008). Increasingly, it is being understood that endothelial progenitor cells (EPCs) have a strong role in vascular repair by contributing to regeneration of the injured endothelial layer. A negative correlation between severity of atherosclerosis and number of EPCs in patients has been established and an increased number of EPCs has been reported to decrease risk 
of stroke. EPCs have been described to express CD34, CD133, or vascular endothelial growth factor receptor 2 . Of the multiple precursors, hemangioblasts, bone marrow-derived monocytic cells, or tissue resident stem cells are prominent (Zampetaki et al., 2008).

Studies in mice demonstrated that circulating EPCs are directly incorporated in the vessel wall and are involved in re-endothelialization (Zampetaki et al., 2008). A study has shown that the newly regenerated ECs in a model of transplant atherosclerosis were derived from circulating blood from the recipient and not from donor vessels (Hu et al., 2003). In fact, disease development can be prevented by treatment with bone marrow-derived progenitor cells from young non-atherosclerotic $\mathrm{ApoE}^{-/-}$mice in aged $\mathrm{ApoE}^{-1-}$ mice (Rauscher et al., 2003). A number of studies have established a direct link between number of EPCs and endothelial repair and reduction in neointima formation (Griese et al., 2003; Wassmann et al., 2006).

However, the new vessel formation supported by these progenitor cells may prove to be detrimental as shown by a study using a hind limb ischemia model in $\mathrm{ApoE}^{-/-}$mice which demonstrated increased plaque size along with improved blood supply to the ischemic areas (Silvestre et al., 2003). Another study observed that EPC treatment led to increased instability of the plaque which can be attributed to their pro-inflammatory effects with a finding of reduced local IL-10 levels. Thus, it seems that EPCs can have opposite effects; impaired mobilization of EPCs may hamper re-endothelialization while excessive mobilization may cause stenosis (Inoue et al., 2007). However, while evaluating the effects of EPCs, their heterogenicity must be considered as different isolation protocols have been shown to affect the functionality of the cells (Seeger et al., 2007). The role of microvessels in the vessel wall in atherogenesis has been emphasized (Kahlon et al., 1992; Moulton et al., 1999; Ross et al., 2001); however, it has also been demonstrated that ECs in these microvessels are derived from progenitor cells (Hu et al., 2003). Thus, considering their role in endothelial repair and plaque angiogenesis, it is clear that EPCs play both beneficial and detrimental roles, at least in transplant atherosclerosis.

\section{Hematopoietic Stem Cells}

Hematopoietic stem cells reside in the arterial tissue and are believed to be involved in maintaining the vascular system on account of their capacity for self-renewal and differentiation to multiple lineages (Feng et al., 2012). Recruitment of circulating blood leukocytes in the vessel wall has been implicated in the development of atherosclerotic plaque (Lusis, 2000; Binder et al., 2002). The role of HSCs in atherosclerosis was investigated recently by inactivating p27 which resulted in enhanced HSC proliferation in arterial macrophages an inflammatory response and accelerated atherosclerosis (Diez-Juan et al., 2004).

\section{Mesenchymal Stem Cells}

Plasticity of MSCs shows their ability to differentiate into several cell types (Narcisi et al., 2015) and is influenced by milieu they are presented with. It has been shown that when primed with chondrogenic factors mimicking the cellular niche present in endochondral ossification, mineralization, and vascularization by MSCs is promoted (Freeman et al., 2016). Processes similar to endochondral or intramembranous ossification also occur in the vascular wall (Neven et al., 2011). In addition, MSCs from bone marrow and resident in the vessel wall, have been demonstrated to differentiate into ECs and SMCs, respectively (Urbich and Dimmeler, 2004a; Torsney et al., 2005).

Circulating MSCs can migrate through the blood stream and reach the site of injury in the vessel wall (Abedin et al., 2004). It is now believed that previously described CVCs in the arterial wall are a type of MSCs, one generation below in mesenchymal hierarchy as suggested by their self-renewal and pluripotent plasticity with lack of adipogenic lineage (Tintut et al., 2003). Regarding the differentiation of MSCs to SMCs, the controversy still remains although, through studies investigating the pathogenesis of transplant arteriosclerosis, the role of MSCs or EPCs in repair of ECs is quite clear along with the apparent role of vascular stem cells in replenishing dead cells (Xu, 2008).

In a study with balloon injury in hyperlipidemic rats, bone marrow-derived MSCs (BM-MSCs) were found to clearly increase the size of atherosclerotic lesions (Liao et al., 2012). In this study, transferring BM-MSCs resulted in VC in medial layers detected at 6 weeks after balloon angioplasty (Liao et al., 2012). Although the exact mechanism of calcification following BM-MSCs transfer is not clear, there was a possible association with upregulation of BMP-2 (Nakagawa et al., 2010; Liao et al., 2012). Evidence suggests that the regulation of this calcification involves locally expressed bone calcification regulatory factors (Hruska et al., 2005; Johnson et al., 2006; Ketteler et al., 2006). Another study has demonstrated that transfer of bone marrow and EPCs not only stimulate disease progression in atherosclerosis but also impacted stability of the plaque (George et al., 2005). Studies have provided enough evidence to suggest a link between MSC transfer and pathogenesis of atherosclerosis (Saiura et al., 2001; Sata et al., 2002).

\section{Vascular Stem Cells}

There is evidence that stem or progenitor cells reside in different organs and differentiate to repair the injury. However, it might be that these resident stem/progenitor cells are not only contributing to the repair but play an important role to the pathogenesis of atherosclerosis (Kawabe and Hasebe, 2014; Yu et al., 2017). A number of cell types present in vessel wall have been shown to potentially be the vascular stem cells (Tilki et al., 2009; Bautch, 2011; Psaltis et al., 2011; Torsney and Xu, 2011; Bostrom et al., 2012). By far, pericytes are the most important VSCs and will be discussed further.

\section{Pericytes}

Pericytes are elongated cells, around $70 \mu \mathrm{m}$ long, embedded within the basement membrane adjacent to the EC junctions (Voisin et al., 2010; Proebstl et al., 2012). Being closely associated with endothelium, they play a crucial function in maintaining vessel wall integrity and contributing to the generation of the venular basement membrane (Armulik et al., 2005; Edelman et al., 2006). Pericytes have been identified in the inner intimal layer and also the outer layer of the media in vasa vasora in adventitia of large, medium, or small arteries and veins. 
It has been suggested that pericytes are MSCs associated with the blood vessel walls where they serve as a support to these vessels (Caplan, 2008, 2017; Crisan et al., 2009). These cells can differentiate not only into fibroblasts, SMC but also into different lineages, especially to osteoblasts (Canfield et al., 1996; Collett and Canfield, 2005; Klein et al., 2011), chondrocytes (Schor et al., 1990; Farrington-Rock et al., 2004; Klein et al., 2011), or adipocytes (Farrington-Rock et al., 2004; Klein et al., 2011) under appropriate cell culture conditions. Pericytes can also act as macrophage precursors and express macrophage markers such as CD4 class I and class II MHC molecules and perform macrophage-like activities (Bergers and Song, 2005; Hall, 2006).

The heterogeneity of pericytes is reflected in their function (Schor et al., 1990). In large arteries, pericytes are embedded within the endothelial basement membrane. They facilitate and integrate cell communication (Armulik et al., 2005). Usually, pericytes overlap several ECs and regulate certain functions by secretion of factors (Armulik et al., 2005; Thanabalasundaram et al., 2011). Pericytes extend long processes exhibiting contractile microfilament bundles which wrap around the blood vessel (Dore-Duffy and Cleary, 2011). They can also form more confined finger like projections and retract them when migrating (Dore-Duffy and Cleary, 2011).

Pericyte coverage varies considerably in different organs, implying their varied functions in different tissues (Proebstl et al., 2012). Similar to VSMCs, pericytes are thought to have multiple origins. In the axial and lateral plate mesenchyme, the vessel wall cells around the developing trunk vessels have been attributed to a mesodermal origin (Hungerford and Little, 1999). In the central nervous system, they might also be derived from neurocrest (Etchevers et al., 2002; Bergers and Song, 2005), at least partly (Etchevers et al., 2001), or mesodermal precursors called angioblasts (Carmeliet, 2004). On the other hand, coronary vessel wall cells have been thought to develop from epicardial cells which have a splanchnic mesodermal origin (Gittenberger-de Groot et al., 1999; Vrancken Peeters et al., 1999). Nevertheless, in general, pericytes are considered to be of mesenchymal origin. They are thought to be associated with MSCs (Creazzo et al., 1998; Armulik et al., 2005; Lamagna and Bergers, 2006) since they can differentiate into different cell types. A study investigating adult angiogenesis confirmed the bone marrow origin of mural cells (Rajantie et al., 2004). Though not a major pathway of pericyte formation in normal physiological development, there has been some evidence of transdifferentiation from ECs (DeRuiter et al., 1997; Rajantie et al., 2004; Armulik et al., 2005), where TGF- $\beta 3$ can initiate the differentiation.

Pericytes are distinguished from other cell types by their marker expression. They express different markers during the different stages of their growth and also depending on their origin. Pericytes are clearly distinguished from other stromal cells such as SMCs and ECs; however, they share many similarities with other cells like myofibroblasts (Alexander et al., 2005). There are several markers which are used to characterize pericytes like $\alpha$-SMA (Morikawa et al., 2002; Song et al., 2005), NG2 (Ozerdem et al., 2002; Song et al., 2005; Klein et al., 2011) (nerve/glial antigen 2), PDGFR- $\beta$ (Winkler et al., 2010; Klein et al., 2011), aminopeptidase A (Ozerdem and Stallcup, 2003), and RGS5 (Gerhardt and Betsholtz, 2003) (regulator of G-protein signaling 5). It is believed that none of the markers absolutely characterize the pericytes on account of their different origins and stage of development. Some of the markers might be expressed dynamically and vary between different organs. 3G5,

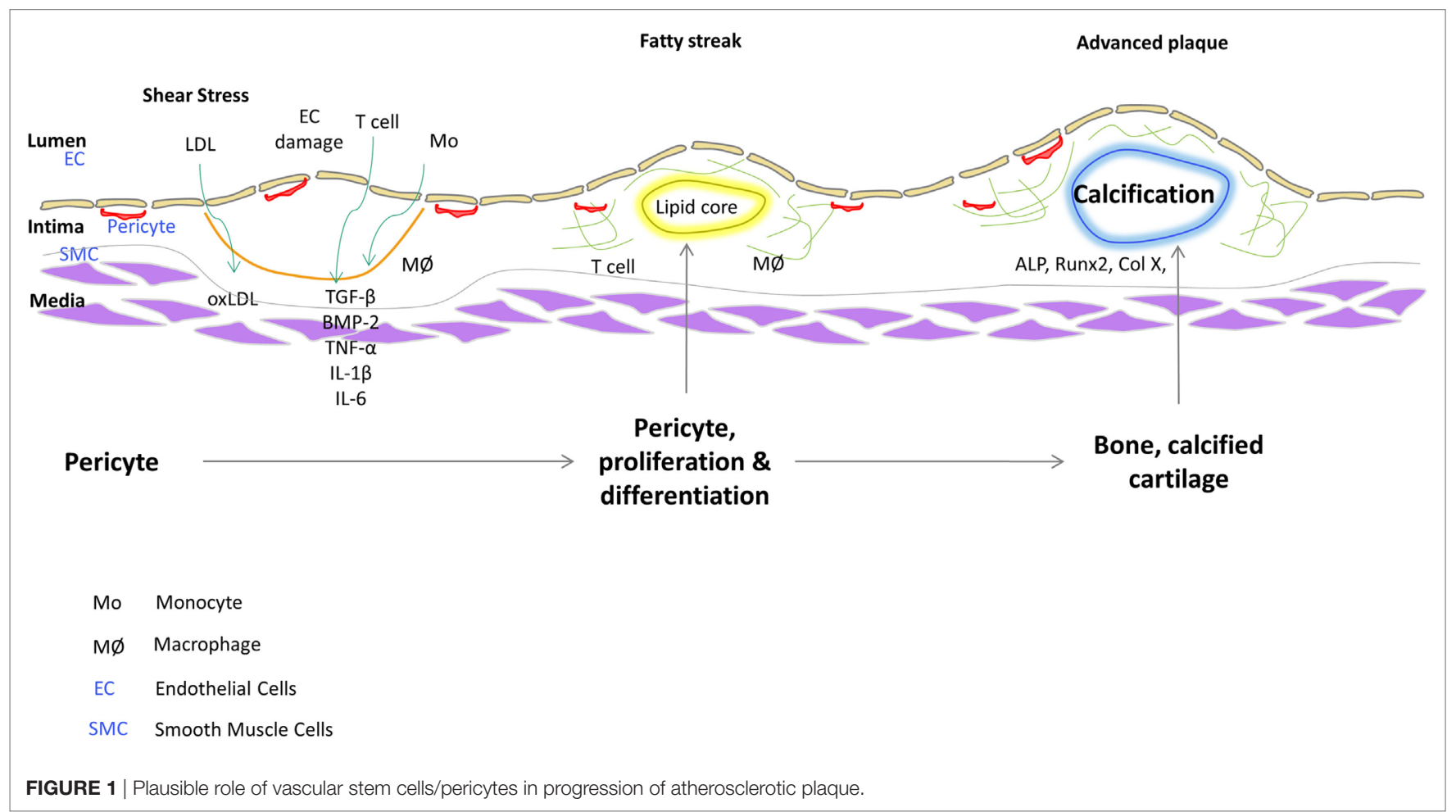


considered to be a pericyte-specific marker is found on the surface of the pericytes (Nayak et al., 1988; Juchem et al., 2010). 3G5 is expressed in pericytes of human and bovine aorta (Bostrom et al., 1993; Juchem et al., 2010). The role of pericytes as cellular models of atherogenesis has recently been reviewed (Ivanova and Orekhov, 2016). Figure 1 shows a schematic that illustrates a role of vascular stem cells or pericytes in atherosclerotic plaque progression based on our findings. In fact, we have described a population of pericyte-like progenitor cells isolated from aortae of $\mathrm{ApoE}^{-/-}$mice and control C57BL/6 mice and shown their possible role in aberrant tissue formation in the atheromatous plaque (Leszczynska et al., 2016).

As we continue to unravel the mysteries underlying disease progression in atherosclerosis and decipher the role of the contributing stem/progenitors in VC, the importance of understanding the cell-cell and cell-tissue communication, especially through the microvesicular/exosomal pathway, cannot be overemphasized. In fact, many studies in recent years have shown important role played by exosomes in communication protocol in atherosclerosis (Huber and Holvoet, 2015; Gao et al., 2016; Perrotta and Aquila, 2016; Lu, 2017).

\section{REFERENCES}

Abedin, M., Tintut, Y., and Demer, L. L. (2004). Mesenchymal stem cells and the artery wall. Circ. Res. 95, 671-676. doi:10.1161/01.RES.0000143421. 27684.12

Alexander, M. Y., Wilkinson, F. L., Kirton, J. P., Rock, C. F., Collett, G. D., Jeziorska, M., et al. (2005). Identification and characterization of vascular calcification-associated factor, a novel gene upregulated during vascular calcification in vitro and in vivo. Arterioscler. Thromb. Vasc. Biol. 25, 1851-1857. doi:10.1161/01. ATV.0000175750.94742.46

Alexopoulos, N., and Raggi, P. (2009). Calcification in atherosclerosis. Nat. Rev. Cardiol. 6, 681-688. doi:10.1038/nrcardio.2009.165

Armulik, A., Abramsson, A., and Betsholtz, C. (2005). Endothelial/pericyte interactions. Circ. Res. 97, 512-523. doi:10.1161/01.RES.0000182903.16652.d7

Bardeesi, A. S. A., Gao, J., Zhang, K., Yu, S., Wei, M., Liu, P., et al. (2017). A novel role of cellular interactions in vascular calcification. J. Transl. Med. 15, 95. doi:10.1186/s12967-017-1190-Z

Bautch, V. L. (2011). Stem cells and the vasculature. Nat. Med. 17, 1437-1443. doi:10.1038/nm.2539

Bentzon, J. F., Sondergaard, C. S., Kassem, M., and Falk, E. (2007). Smooth muscle cells healing atherosclerotic plaque disruptions are of local, not blood, origin in apolipoprotein E knockout mice. Circulation 116, 2053-2061. doi:10.1161/ CIRCULATIONAHA.107.722355

Bentzon, J. F., Weile, C., Sondergaard, C. S., Hindkjaer, J., Kassem, M., and Falk, E. (2006). Smooth muscle cells in atherosclerosis originate from the local vessel wall and not circulating progenitor cells in ApoE knockout mice. Arterioscler. Thromb. Vasc. Biol. 26, 2696-2702. doi:10.1161/01.ATV.0000247243. $48542.9 \mathrm{~d}$

Bergers, G., and Song, S. (2005). The role of pericytes in blood-vessel formation and maintenance. Neuro Oncol. 7, 452-464. doi:10.1215/S1152851705000232

Bessueille, L., and Magne, D. (2015). Inflammation: a culprit for vascular calcification in atherosclerosis and diabetes. Cell. Mol. Life Sci. 72, 2475-2489. doi:10.1007/s00018-015-1876-4

Binder, C. J., Chang, M. K., Shaw, P. X., Miller, Y. I., Hartvigsen, K., Dewan, A., et al. (2002). Innate and acquired immunity in atherogenesis. Nat. Med. 8, 1218-1226. doi:10.1038/nm1102-1218

Bostrom, K., Watson, K. E., Horn, S., Wortham, C., Herman, I. M., and Demer, L. L. (1993). Bone morphogenetic protein expression in human atherosclerotic lesions. J. Clin. Invest. 91, 1800-1809. doi:10.1172/JCI116391

Bostrom, K. I. (2016). Where do we stand on vascular calcification? Vascul. Pharmacol. 84, 8-14. doi:10.1016/j.vph.2016.05.014

\section{CONCLUSION}

A number of stem progenitor cells are involved in VC, in fact they are emerging as the most important players. On account of their plasticity and involvement in VC and inflammation, pericytes are arguably the most interesting ones among the different contributors. Going forward, it will be increasingly important to understand how exosomes execute the bio-message delivery among different key players and exploit therapeutic potential thereof.

\section{AUTHOR CONTRIBUTIONS}

$\mathrm{AL}$ and JMM conceived the idea of this article. AL wrote this mini review and JMM revised and finalized it.

\section{FUNDING}

This work was supported by the Irish Research Council for Science, Engineering and Technology, and Science Foundation Ireland under grant no. 09/SRC/B1794.

Bostrom, K. I., Garfinkel, A., Yao, Y., and Jumabay, M. (2012). Concise review: applying stem cell biology to vascular structures. Stem Cells 30, 386-391. doi:10.1002/stem.1027

Bunting, C. H. (1906). The formation of true bone with cellular (red) marrow in a sclerotic aorta. J. Exp. Med. 8, 365-376. doi:10.1084/jem.8.3.365

Burke, A. P., Kolodgie, F. D., Farb, A., Weber, D. K., Malcom, G. T., Smialek, J., et al. (2001). Healed plaque ruptures and sudden coronary death: evidence that subclinical rupture has a role in plaque progression. Circulation 103, 934-940. doi:10.1161/01.CIR.103.7.934

Bussolati, B., Deregibus, M. C., and Camussi, G. (2017). Role of adventitial MSC-like cells in chronic kidney disease. Stem Cell Investig. 4, 2. doi:10.21037/ sci.2016.12.03

Canfield, A. E., Doherty, M. J., Wood, A. C., Farrington, C., Ashton, B., Begum, N., et al. (2000). Role of pericytes in vascular calcification: a review. Z. Kardiol. 89(Suppl. 2), 20-27. doi:10.1007/s003920070096

Canfield, A. E., Sutton, A. B., Hoyland, J. A., and Schor, A. M. (1996). Association of thrombospondin-1 with osteogenic differentiation of retinal pericytes in vitro. J. Cell. Sci. 109(Pt 2), 343-353.

Caplan, A. I. (2008). All MSCs are pericytes? Cell Stem Cell3,229-230. doi:10.1016/j. stem.2008.08.008

Caplan, A. I. (2017). New MSC: MSCs as pericytes are sentinels and gatekeepers. J. Orthop. Res. 35, 1151-1159. doi:10.1002/jor.23560

Cappendijk, V. C., Cleutjens, K. B., Kessels, A. G., Heeneman, S., Schurink, G. W., Welten, R. J., et al. (2005). Assessment of human atherosclerotic carotid plaque components with multisequence MR imaging: initial experience. Radiology 234, 487-492. doi:10.1148/radiol.2342032101

Carmeliet, P. (2004). Manipulating angiogenesis in medicine. J. Intern. Med. 255, 538-561. doi:10.1111/j.1365-2796.2003.01297.x

Cho, H. J., Cho, H. J., Lee, H. J., Song, M. K., Seo, J. Y., Bae, Y. H., et al. (2013). Vascular calcifying progenitor cells possess bidirectional differentiation potentials. PLoS Biol. 11:e1001534. doi:10.1371/journal.pbio.1001534

Cianciolo, G., Capelli, I., Cappuccilli, M., Schillaci, R., Cozzolino, M., and La Manna, G. (2016). Calcifying circulating cells: an uncharted area in the setting of vascular calcification in CKD patients. Clin. Kidney J. 9, 280-286. doi: $10.1093 / \mathrm{ckj} / \mathrm{sfv} 145$

Collett, G. D., and Canfield, A. E. (2005). Angiogenesis and pericytes in the initiation of ectopic calcification. Circ. Res. 96, 930-938. doi:10.1161/01. RES.0000163634.51301.0d

Creazzo, T. L., Godt, R. E., Leatherbury, L., Conway, S. J., and Kirby, M. L. (1998). Role of cardiac neural crest cells in cardiovascular development. Annu. Rev. Physiol. 60, 267-286. doi:10.1146/annurev.physiol.60.1.267 
Crisan, M., Chen, C. W., Corselli, M., Andriolo, G., Lazzari, L., and Peault, B. (2009). Perivascular multipotent progenitor cells in human organs. Ann. N. Y. Acad. Sci. 1176, 118-123. doi:10.1111/j.1749-6632.2009.04967.x

da Silva Meirelles, L., Chagastelles, P. C., and Nardi, N. B. (2006). Mesenchymal stem cells reside in virtually all post-natal organs and tissues. J. Cell. Sci. 119(Pt 11), 2204-2213. doi:10.1242/jcs.02932

Dallas, S. L., and Bonewald, L. F. (2010). Dynamics of the transition from osteoblast to osteocyte. Ann. N. Y. Acad. Sci. 1192, 437-443. doi:10.1111/j.1749-6632.2009.05246.x

Daniel, J. M., Bielenberg, W., Stieger, P., Weinert, S., Tillmanns, H., and Sedding, D. G. (2010). Time-course analysis on the differentiation of bone marrow-derived progenitor cells into smooth muscle cells during neointima formation. Arterioscler. Thromb. Vasc. Biol. 30, 1890-1896. doi:10.1161/ ATVBAHA.110.209692

Davaine, J. M., Quillard, T., Brion, R., Laperine, O., Guyomarch, B., Merlini, T., et al. (2014). Osteoprotegerin, pericytes and bone-like vascular calcification are associated with carotid plaque stability. PLOS ONE 9:e107642. doi:10.1371/ journal.pone.0107642

DeRuiter, M. C., Poelmann, R. E., VanMunsteren, J. C., Mironov, V., Markwald, R. R., and Gittenberger-de Groot, A. C. (1997). Embryonic endothelial cells transdifferentiate into mesenchymal cells expressing smooth muscle actins in vivo and in vitro. Circ. Res. 80, 444-451. doi:10.1161/01.RES.80. 4.444

Diez-Juan, A., Perez, P., Aracil, M., Sancho, D., Bernad, A., Sanchez-Madrid, F., et al. (2004). Selective inactivation of p27(Kip1) in hematopoietic progenitor cells increases neointimal macrophage proliferation and accelerates atherosclerosis. Blood 103, 158-161. doi:10.1182/blood-2003-07-2319

Dore-Duffy, P., and Cleary, K. (2011). Morphology and properties of pericytes. Methods Mol. Biol. 686, 49-68. doi:10.1007/978-1-60761-938-3_2

Edelman, D. A., Jiang, Y., Tyburski, J., Wilson, R. F., and Steffes, C. (2006). Pericytes and their role in microvasculature homeostasis. J. Surg. Res. 135, 305-311. doi:10.1016/j.jss.2006.06.010

Etchevers, H. C., Couly, G., and Le Douarin, N. M. (2002). Morphogenesis of the branchial vascular sector. Trends Cardiovasc. Med. 12, 299-304. doi:10.1016/ S1050-1738(02)00178-0

Etchevers, H. C., Vincent, C., Le Douarin, N. M., and Couly, G. F. (2001). The cephalic neural crest provides pericytes and smooth muscle cells to all blood vessels of the face and forebrain. Development 128, 1059-1068.

Ewence, A. E., Bootman, M., Roderick, H. L., Skepper, J. N., McCarthy, G., Epple, M., et al. (2008). Calcium phosphate crystals induce cell death in human vascular smooth muscle cells: a potential mechanism in atherosclerotic plaque destabilization. Circ. Res. 103, e28-e34. doi:10.1161/CIRCRESAHA.108.181305

Farrington-Rock, C., Crofts, N. J., Doherty, M. J., Ashton, B. A., Griffin-Jones, C., and Canfield, A. E. (2004). Chondrogenic and adipogenic potential of microvascular pericytes. Circulation 110, 2226-2232. doi:10.1161/01. CIR.0000144457.55518.E5

Feng, Y., Schouteden, S., Geenens, R., Van Duppen, V., Herijgers, P., Holvoet, P., et al. (2012). Hematopoietic stem/progenitor cell proliferation and differentiation is differentially regulated by high-density and low-density lipoproteins in mice. PLoS ONE 7:e47286. doi:10.1371/journal.pone.0047286

Freeman, F. E., Stevens, H. Y., Owens, P., Guldberg, R. E., and McNamara, L. M. (2016). Osteogenic differentiation of mesenchymal stem cells by mimicking the cellular niche of the endochondral template. Tissue Eng. Part A 22, 1176-1190. doi:10.1089/ten.TEA.2015.0339

Frid, M. G., Moiseeva, E. P., and Stenmark, K. R. (1994). Multiple phenotypically distinct smooth muscle cell populations exist in the adult and developing bovine pulmonary arterial media in vivo. Circ. Res. 75, 669-681. doi:10.1161/01. RES.75.4.669

Gao, W., Liu, H., Yuan, J., Wu, C., Huang, D., Ma, Y., et al. (2016). Exosomes derived from mature dendritic cells increase endothelial inflammation and atherosclerosis via membrane TNF-alpha mediated NF-kappaB pathway. J. Cell. Mol. Med. 20, 2318-2327. doi:10.1111/jcmm.12923

George, J., Afek, A., Abashidze, A., Shmilovich, H., Deutsch, V., Kopolovich, J., et al. (2005). Transfer of endothelial progenitor and bone marrow cells influences atherosclerotic plaque size and composition in apolipoprotein E knockout mice. Arterioscler. Thromb. Vasc. Biol. 25, 2636-2641. doi:10.1161/01. ATV.0000188554.49745.9e

Gerhardt, H., and Betsholtz, C. (2003). Endothelial-pericyte interactions in angiogenesis. Cell Tissue Res. 314, 15-23. doi:10.1007/s00441-003-0745-x
Gittenberger-de Groot, A. C., DeRuiter, M. C., Bergwerff, M., and Poelmann, R. E. (1999). Smooth muscle cell origin and its relation to heterogeneity in development and disease. Arterioscler. Thromb. Vasc. Biol. 19, 1589-1594. doi:10.1161/01.ATV.19.7.1589

Griese, D. P., Ehsan, A., Melo, L. G., Kong, D., Zhang, L., Mann, M. J., et al. (2003). Isolation and transplantation of autologous circulating endothelial cells into denuded vessels and prosthetic grafts: implications for cell-based vascular therapy. Circulation 108, 2710-2715. doi:10.1161/01.CIR.0000096490.16596.A6

Hall, A. P. (2006). Review of the pericyte during angiogenesis and its role in cancer and diabetic retinopathy. Toxicol. Pathol. 34, 763-775. doi:10.1080/01926230600936290

Hao, H., Gabbiani, G., Camenzind, E., Bacchetta, M., Virmani, R., and BochatonPiallat, M. L. (2006). Phenotypic modulation of intima and media smooth muscle cells in fatal cases of coronary artery lesion. Arterioscler. Thromb. Vasc. Biol. 26, 326-332. doi:10.1161/01.ATV.0000199393.74656.4c

Hillebrands, J. L., Klatter, F. A., and Rozing, J. (2003). Origin of vascular smooth muscle cells and the role of circulating stem cells in transplant arteriosclerosis. Arterioscler. Thromb. Vasc. Biol. 23, 380-387. doi:10.1161/01. ATV.0000059337.60393.64

Hruska, K. A., Mathew, S., and Saab, G. (2005). Bone morphogenetic proteins in vascular calcification. Circ. Res. 97, 105-114. doi:10.1161/01. RES.00000175571.53833.6c

Hu, Y., Davison, F., Ludewig, B., Erdel, M., Mayr, M., Url, M., et al. (2002). Smooth muscle cells in transplant atherosclerotic lesions are originated from recipients, but not bone marrow progenitor cells. Circulation 106, 1834-1839. doi:10.1161/01.CIR.0000031333.86845.DD

Hu, Y., Davison, F., Zhang, Z., and Xu, Q. (2003). Endothelial replacement and angiogenesis in arteriosclerotic lesions of allografts are contributed by circulating progenitor cells. Circulation 108, 3122-3127. doi:10.1161/01. CIR.0000105722.96112.67

Hu, Y., Zhang, Z., Torsney, E., Afzal, A. R., Davison, F., Metzler, B., et al. (2004). Abundant progenitor cells in the adventitia contribute to atherosclerosis of vein grafts in ApoE-deficient mice. J. Clin. Invest. 113, 1258-1265. doi:10.1172/ JCI19628

Huber, H. J., and Holvoet, P. (2015). Exosomes: emerging roles in communication between blood cells and vascular tissues during atherosclerosis. Curr. Opin. Lipidol. 26, 412-419. doi:10.1097/MOL.0000000000000214

Hungerford, J. E., and Little, C. D. (1999). Developmental biology of the vascular smooth muscle cell: building a multilayered vessel wall. J. Vasc. Res. 36, 2-27. doi:10.1159/000025622

Hunt, J. L., Fairman, R., Mitchell, M. E., Carpenter, J. P., Golden, M., Khalapyan, T., et al. (2002). Bone formation in carotid plaques: a clinicopathological study. Stroke 33, 1214-1219. doi:10.1161/01.STR.0000013741.41309.67

Inoue, T., Sata, M., Hikichi, Y., Sohma, R., Fukuda, D., Uchida, T., et al. (2007). Mobilization of CD34-positive bone marrow-derived cells after coronary stent implantation: impact on restenosis. Circulation 115, 553-561. doi:10.1161/ CIRCULATIONAHA.106.621714

Ivanova, E. A., and Orekhov, A. N. (2016). Cellular model of atherogenesis based on pluripotent vascular wall pericytes. Stem Cells Int. 2016, 7321404. doi:10.1155/2016/7321404

Johnson, R. C., Leopold, J. A., and Loscalzo, J. (2006). Vascular calcification: pathobiological mechanisms and clinical implications. Circ. Res. 99, 1044-1059. doi:10.1161/01.RES.0000249379.55535.21

Juchem, G., Weiss, D. R., Gansera, B., Kemkes, B. M., Mueller-Hoecker, J., and Nees, S. (2010). Pericytes in the macrovascular intima: possible physiological and pathogenetic impact. Am. J. Physiol. Heart Circ. Physiol. 298, H754-H770. doi:10.1152/ajpheart.00343.2009

Kahlon, R., Shapero, J., and Gotlieb, A. I. (1992). Angiogenesis in atherosclerosis. Can. J. Cardiol. 8, 60-64.

Kataoka, T., Mathew, V., Rubinshtein, R., Rihal, C. S., Lennon, R., Lerman, L. O., et al. (2009). Association of plaque composition and vessel remodeling in atherosclerotic renal artery stenosis: a comparison with coronary artery disease. JACC Cardiovasc. Imaging 2, 327-338. doi:10.1016/j.jcmg.2008.08.008

Kawabe, J., and Hasebe, N. (2014). Role of the vasa vasorum and vascular resident stem cells in atherosclerosis. Biomed Res. Int. 2014, 701571. doi:10.1155/2014/701571

Ketteler, M., Schlieper, G., and Floege, J. (2006). Calcification and cardiovascular health: new insights into an old phenomenon. Hypertension 47, 1027-1034. doi:10.1161/01.HYP.0000219635.51844.da 
Kirton, J. P., Wilkinson, F. L., Canfield, A. E., and Alexander, M. Y. (2006). Dexamethasone downregulates calcification-inhibitor molecules and accelerates osteogenic differentiation of vascular pericytes: implications for vascular calcification. Circ. Res. 98, 1264-1272. doi:10.1161/01.RES.0000223056.68892.8b

Klein, D., Weisshardt, P., Kleff, V., Jastrow, H., Jakob, H. G., and Ergun, S. (2011). Vascular wall-resident CD44+ multipotent stem cells give rise to pericytes and smooth muscle cells and contribute to new vessel maturation. PLoS ONE 6:e20540. doi:10.1371/journal.pone.0020540

Kramann, R., Goettsch, C., Wongboonsin, J., Iwata, H., Schneider, R. K., Kuppe, C., et al. (2016). Adventitial MSC-like cells are progenitors of vascular smooth muscle cells and drive vascular calcification in chronic kidney disease. Cell Stem Cell 19, 628-642. doi:10.1016/j.stem.2016.08.001

Lamagna, C., and Bergers, G. (2006). The bone marrow constitutes a reservoir of pericyte progenitors. J. Leukoc. Biol. 80, 677-681. doi:10.1189/jlb.0506309

Leszczynska, A., O’Doherty, A., Farrell, E., Pindjakova, J., O’Brien, F. J., O’Brien, T., et al. (2016). Differentiation of vascular stem cells contributes to ectopic calcification of atherosclerotic plaque. Stem Cells 34, 913-923. doi:10.1002/ stem. 2315

Liao, J., Chen, X., Li, Y., Ge, Z., Duan, H., Zou, Y., et al. (2012). Transfer of bone-marrow-derived mesenchymal stem cells influences vascular remodeling and calcification after balloon injury in hyperlipidemic rats. J. Biomed. Biotechnol. 2012, 165296. doi:10.1155/2012/165296

$\mathrm{Lu}, \mathrm{X}$. (2017). The role of exosomes and exosome-derived microRNAs in atherosclerosis. Curr. Pharm. Des. doi:10.2174/1381612823666170413125507

Lusis, A. J. (2000). Atherosclerosis. Nature 407, 233-241. doi:10.1038/35025203

Mann, J., and Davies, M. J. (1999). Mechanisms of progression in native coronary artery disease: role of healed plaque disruption. Heart 82, 265-268. doi:10.1136/ hrt.82.3.265

Martinez-Agosto, J. A., Mikkola, H. K., Hartenstein, V., and Banerjee, U. (2007). The hematopoietic stem cell and its niche: a comparative view. Genes Dev. 21, 3044-3060. doi:10.1101/gad.1602607

Matthews, C., Gorenne, I., Scott, S., Figg, N., Kirkpatrick, P., Ritchie, A., et al. (2006). Vascular smooth muscle cells undergo telomere-based senescence in human atherosclerosis: effects of telomerase and oxidative stress. Circ. Res. 99, 156-164. doi:10.1161/01.RES.0000233315.38086.bc

Minamino, T., and Komuro, I. (2008). Vascular aging: insights from studies on cellular senescence, stem cell aging, and progeroid syndromes. Nat. Clin. Pract. Cardiovasc. Med. 5, 637-648. doi:10.1038/ncpcardio1324

Morikawa, S., Baluk, P., Kaidoh, T., Haskell, A., Jain, R. K., and McDonald, D. M. (2002). Abnormalities in pericytes on blood vessels and endothelial sprouts in tumors. Am. J. Pathol. 160, 985-1000. doi:10.1016/S0002-9440(10)64920-6

Moulton, K. S., Heller, E., Konerding, M. A., Flynn, E., Palinski, W., and Folkman, J. (1999). Angiogenesis inhibitors endostatin or TNP-470 reduce intimal neovascularization and plaque growth in apolipoprotein E-deficient mice. Circulation 99, 1726-1732. doi:10.1161/01.CIR.99.13.1726

Nakagawa, Y., Ikeda, K., Akakabe, Y., Koide, M., Uraoka, M., Yutaka, K. T., et al. (2010). Paracrine osteogenic signals via bone morphogenetic protein-2 accelerate the atherosclerotic intimal calcification in vivo. Arterioscler. Thromb. Vasc. Biol. 30, 1908-1915. doi:10.1161/ATVBAHA.110.206185

Nakahara, T., Dweck, M. R., Narula, N., Pisapia, D., Narula, J., and Strauss, H. W. (2017). Coronary artery calcification: from mechanism to molecular imaging. JACC Cardiovasc. Imaging 10, 582-593. doi:10.1016/j.jcmg.2017.03.005

Narcisi, R., Cleary, M. A., Brama, P. A., Hoogduijn, M. J., Tuysuz, N., ten Berge, D., et al. (2015). Long-term expansion, enhanced chondrogenic potential, and suppression of endochondral ossification of adult human MSCs via WNT signaling modulation. Stem Cell Reports 4, 459-472. doi:10.1016/j.stemcr.2015.01.017

Nayak, R. C., Berman, A. B., George, K. L., Eisenbarth, G. S., and King, G. L. (1988). A monoclonal antibody (3G5)-defined ganglioside antigen is expressed on the cell surface of microvascular pericytes. J. Exp. Med. 167, 1003-1015. doi:10.1084/jem.167.3.1003

Neven, E., De Schutter, T. M., De Broe, M. E., and D’Haese, P. C. (2011). Cell biological and physicochemical aspects of arterial calcification. Kidney Int. 79, 1166-1177. doi:10.1038/ki.2011.59

Neven, E., and D'Haese, P. C. (2011). Vascular calcification in chronic renal failure: what have we learned from animal studies? Circ. Res. 108, 249-264. doi:10.1161/ CIRCRESAHA.110.225904

Ozerdem, U., Monosov, E., and Stallcup, W. B. (2002). NG2 proteoglycan expression by pericytes in pathological microvasculature. Microvasc. Res. 63, 129-134. doi:10.1006/mvre.2001.2376
Ozerdem, U., and Stallcup, W. B. (2003). Early contribution of pericytes to angiogenic sprouting and tube formation. Angiogenesis 6, 241-249. doi:10.1023/B:AGEN.0000021401.58039.a9

Perrotta, I., and Aquila, S. (2016). Exosomes in human atherosclerosis: an ultrastructural analysis study. Ultrastruct. Pathol. 40, 101-106. doi:10.3109/019131 23.2016.1154912

Proebstl, D., Voisin, M. B., Woodfin, A., Whiteford, J., D’Acquisto, F., Jones, G. E., et al. (2012). Pericytes support neutrophil subendothelial cell crawling and breaching of venular walls in vivo. J. Exp. Med. 209, 1219-1234. doi:10.1084/ jem.20111622

Psaltis, P. J., Harbuzariu, A., Delacroix, S., Holroyd, E. W., and Simari, R. D. (2011). Resident vascular progenitor cells-diverse origins, phenotype, and function. J. Cardiovasc. Transl. Res. 4, 161-176. doi:10.1007/s12265-010-9248-9

Rajamannan, N. M., Bonow, R. O., and Rahimtoola, S. H. (2007). Calcific aortic stenosis: an update. Nat. Clin. Pract. Cardiovasc. Med. 4, 254-262. doi:10.1038/ ncpcardio0827

Rajantie, I., Ilmonen, M., Alminaite, A., Ozerdem, U., Alitalo, K., and Salven, P. (2004). Adult bone marrow-derived cells recruited during angiogenesis comprise precursors for periendothelial vascular mural cells. Blood 104, 2084-2086. doi:10.1182/blood-2004-01-0336

Rauscher, F. M., Goldschmidt-Clermont, P. J., Davis, B. H., Wang, T., Gregg, D., Ramaswami, P., et al. (2003). Aging, progenitor cell exhaustion, and atherosclerosis. Circulation 108, 457-463. doi:10.1161/01.CIR.0000082924. 75945.48

Ross, J. S., Stagliano, N. E., Donovan, M. J., Breitbart, R. E., and Ginsburg, G. S. (2001). Atherosclerosis and cancer: common molecular pathways of disease development and progression. Ann. N. Y. Acad. Sci. 947, 271-92; discussion 292-73. doi:10.1111/j.1749-6632.2001.tb03949.x

Rossig, L., Dimmeler, S., and Zeiher, A. M. (2001). Apoptosis in the vascular wall and atherosclerosis. Basic Res. Cardiol. 96, 11-22. doi:10.1007/s003950170073

Saiura, A., Sata, M., Hirata, Y., Nagai, R., and Makuuchi, M. (2001). Circulating smooth muscle progenitor cells contribute to atherosclerosis. Nat. Med. 7, 382-383. doi:10.1038/86394

Sata, M., Saiura, A., Kunisato, A., Tojo, A., Okada, S., Tokuhisa, T., et al. (2002). Hematopoietic stem cells differentiate into vascular cells that participate in the pathogenesis of atherosclerosis. Nat. Med. 8, 403-409. doi:10.1038/nm0402-403

Schor, A. M., Allen, T. D., Canfield, A. E., Sloan, P., and Schor, S. L. (1990). Pericytes derived from the retinal microvasculature undergo calcification in vitro. J. Cell. Sci. 97(Pt 3), 449-461.

Schwartz, S. M., Virmani, R., and Rosenfeld, M. E. (2000). The good smooth muscle cells in atherosclerosis. Curr. Atheroscler. Rep. 2, 422-429. doi:10.1007/ s11883-000-0081-5

Seeger, F. H., Tonn, T., Krzossok, N., Zeiher, A. M., and Dimmeler, S. (2007). Cell isolation procedures matter: a comparison of different isolation protocols of bone marrow mononuclear cells used for cell therapy in patients with acute myocardial infarction. Eur. Heart J. 28, 766-772. doi:10.1093/eurheartj/ ehl509

Silvestre, J. S., Gojova, A., Brun, V., Potteaux, S., Esposito, B., Duriez, M., et al. (2003). Transplantation of bone marrow-derived mononuclear cells in ischemic apolipoprotein E-knockout mice accelerates atherosclerosis without altering plaque composition. Circulation 108, 2839-2842. doi:10.1161/01. CIR.0000106161.43954.DF

Song, S., Ewald, A. J., Stallcup, W., Werb, Z., and Bergers, G. (2005). PDGFRbeta+ perivascular progenitor cells in tumours regulate pericyte differentiation and vascular survival. Nat. Cell Biol. 7, 870-879. doi:10.1038/ncb1288

Soor, G. S., Vukin, I., Leong, S. W., Oreopoulos, G., and Butany, J. (2008). Peripheral vascular disease: who gets it and why? A histomorphological analysis of 261 arterial segments from 58 cases. Pathology 40, 385-391. doi:10.1080/00313020802036764

Speer, M. Y., Yang, H. Y., Brabb, T., Leaf, E., Look, A., Lin, W. L., et al. (2009). Smooth muscle cells give rise to osteochondrogenic precursors and chondrocytes in calcifying arteries. Circ. Res. 104, 733-741. doi:10.1161/CIRCRESAHA. 108.183053

Tanaka, K., Sata, M., Natori, T., Kim-Kaneyama, J. R., Nose, K., Shibanuma, M., et al. (2008). Circulating progenitor cells contribute to neointimal formation in nonirradiated chimeric mice. FASEB J. 22, 428-436. doi:10.1096/fj.06-6884com

Thanabalasundaram, G., El-Gindi, J., Lischper, M., and Galla, H. J. (2011). Methods to assess pericyte-endothelial cell interactions in a coculture model. Methods Mol. Biol. 686, 379-399. doi:10.1007/978-1-60761-938-3_19 
Tigges, U., Komatsu, M., and Stallcup, W. B. (2013). Adventitial pericyte progenitor/mesenchymal stem cells participate in the restenotic response to arterial injury. J. Vasc. Res. 50, 134-144. doi:10.1159/000345524

Tilki, D., Hohn, H. P., Ergun, B., Rafii, S., and Ergun, S. (2009). Emerging biology of vascular wall progenitor cells in health and disease. Trends Mol. Med. 15, 501-509. doi:10.1016/j.molmed.2009.09.004

Ting, T. C., Miyazaki-Anzai, S., Masuda, M., Levi, M., Demer, L. L., Tintut, Y., et al. (2011). Increased lipogenesis and stearate accelerate vascular calcification in calcifying vascular cells. J. Biol. Chem. 286, 23938-23949. doi:10.1074/jbc. M111.237065

Tintut, Y., Alfonso, Z., Saini, T., Radcliff, K., Watson, K., Bostrom, K., et al. (2003). Multilineage potential of cells from the artery wall. Circulation 108, 2505-2510. doi:10.1161/01.CIR.0000096485.64373.C5

Tintut, Y., Parhami, F., Bostrom, K., Jackson, S. M., and Demer, L. L. (1998). cAMP stimulates osteoblast-like differentiation of calcifying vascular cells. Potential signaling pathway for vascular calcification. J. Biol. Chem. 273, 7547-7553. doi:10.1074/jbc.273.13.7547

Torsney, E., Hu, Y., and Xu, Q. (2005). Adventitial progenitor cells contribute to arteriosclerosis. Trends Cardiovasc. Med. 15, 64-68. doi:10.1016/j.tcm.2005.02.003

Torsney, E., Mandal, K., Halliday, A., Jahangiri, M., and Xu, Q. (2007). Characterisation of progenitor cells in human atherosclerotic vessels. Atherosclerosis 191, 259-264. doi:10.1016/j.atherosclerosis.2006.05.033

Torsney, E., and Xu, Q. (2011). Resident vascular progenitor cells. J. Mol. Cell. Cardiol. 50, 304-311. doi:10.1016/j.yjmcc.2010.09.006

Urbich, C., and Dimmeler, S. (2004a). Endothelial progenitor cells functional characterization. Trends Cardiovasc. Med. 14, 318-322. doi:10.1016/j. tcm.2004.10.001

Urbich, C., and Dimmeler, S. (2004b). Endothelial progenitor cells: characterization and role in vascular biology. Circ. Res. 95, 343-353. doi:10.1161/01. RES.0000137877.89448.78

Voisin, M. B., Probstl, D., and Nourshargh, S. (2010). Venular basement membranes ubiquitously express matrix protein low-expression regions: characterization in multiple tissues and remodeling during inflammation. Am. J. Pathol. 176, 482-495. doi:10.2353/ajpath.2010.090510

Vrancken Peeters, M. P., Gittenberger-de Groot, A. C., Mentink, M. M., and Poelmann, R. E. (1999). Smooth muscle cells and fibroblasts of the coronary arteries derive from epithelial-mesenchymal transformation of the epicardium. Anat. Embryol. (Berl) 199, 367-378. doi:10.1007/s004290050235
Wassmann, S., Werner, N., Czech, T., and Nickenig, G. (2006). Improvement of endothelial function by systemic transfusion of vascular progenitor cells. Circ. Res. 99, e74-e83. doi:10.1161/01.RES.0000246095.90247.d4

Watson, K. E., Bostrom, K., Ravindranath, R., Lam, T., Norton, B., and Demer, L. L. (1994). TGF-beta 1 and 25-hydroxycholesterol stimulate osteoblast-like vascular cells to calcify. J. Clin. Invest. 93, 2106-2113. doi:10.1172/JCI117205

Winkler, E. A., Bell, R. D., and Zlokovic, B. V. (2010). Pericyte-specific expression of PDGF beta receptor in mouse models with normal and deficient PDGF beta receptor signaling. Mol. Neurodegener. 5, 32. doi:10.1186/1750-1326-5-32

Wirrig, E. E., and Yutzey, K. E. (2014). Conserved transcriptional regulatory mechanisms in aortic valve development and disease. Arterioscler. Thromb. Vasc. Biol. 34, 737-741. doi:10.1161/ATVBAHA.113.302071

$\mathrm{Xu}, \mathrm{Q}$. (2008). Stem cells and transplant arteriosclerosis. Circ. Res. 102, 1011-1024. doi:10.1161/CIRCRESAHA.108.171488

Yao, J., Guihard, P. J., Blazquez-Medela, A. M., Guo, Y., Moon, J. H., Jumabay, M., et al. (2015). Serine protease activation essential for endothelial-mesenchymal transition in vascular calcification. Circ. Res. 117, 758-769. doi:10.1161/ CIRCRESAHA.115.306751

Yu, B., Chen, Q., Le Bras, A., Zhang, L., and Xu, Q. (2017). Vascular stem/progenitor cell migration and differentiation in atherosclerosis. Antioxid. Redox Signal. doi:10.1089/ars.2017.7171

Zampetaki, A., Kirton, J. P., and Xu, Q. (2008). Vascular repair by endothelial progenitor cells. Cardiovasc. Res. 78, 413-421. doi:10.1093/cvr/cvn081

Zoll, J., Fontaine, V., Gourdy, P., Barateau, V., Vilar, J., Leroyer, A., et al. (2008). Role of human smooth muscle cell progenitors in atherosclerotic plaque development and composition. Cardiovasc. Res. 77, 471-480. doi:10.1093/cvr/cvm034

Conflict of Interest Statement: The authors declare that the research was conducted in the absence of any commercial or financial relationships that could be construed as a potential conflict of interest.

Copyright (C) 2018 Leszczynska and Murphy. This is an open-access article distributed under the terms of the Creative Commons Attribution License (CC $B Y)$. The use, distribution or reproduction in other forums is permitted, provided the original author(s) and the copyright owner are credited and that the original publication in this journal is cited, in accordance with accepted academic practice. No use, distribution or reproduction is permitted which does not comply with these terms. 